\title{
Estimation and comparison of reference evapotranspiration using different methods to determine olive trees irrigation schedule in different bioclimatic stages of Tunisia
}

\section{Amani Bchir ${ }^{1}$,*, Raoul Lemeur ${ }^{2}$, Fethi Ben Mariem ${ }^{1}$, Najet Boukherissa $^{3}$, Wafa Gariani ${ }^{1}$, Haifa Sbaii ${ }^{1}$, Ali Ben Dhiab ${ }^{1}$, Samia Ben Mansour Gueddes ${ }^{1}$ and Mohamed Braham ${ }^{1}$}

\footnotetext{
${ }^{1}$ Olive Tree Institute. University of Sfax. Tunisia. *Email: ameni.bchir@gmail.com.

${ }^{2}$ Laboratory of Plant Ecology. Gent University. Belgium.

${ }^{3}$ Regional Commissary for Agricultural Development of Sousse. Tunisia.
}

\begin{abstract}
The study of olive trees water requirements allows a better water management by using more accurate methods including maximum parameters of the continuum soil-plantatmosphere. The Penman-Monteith equations is consideredas the most rational approach and the most reliable for calculating evapotranspiration. Only this approach necessarily requires an important number of climate parameters. The use of other equations, less complicated and using less climate parameters may be a reliable and efficient alternative. This experimental study was carried out on two cultivars cv. "Meski" and cv. "Chemlali" conducted in the intensive system in different bioclimatic stages (Subhumid, Semi-Arid and Arid) in Tunisia. This work aims to estimate olive trees water needs using evapotranspiration calculation in three different bioclimatic stages. For that, we compared the Penman-Monteith formula with Blaney-Criddel, Hargreaves-Temperature, HargreavesRadiation and Priestley-Taylor formulas to estimate reference evapotranspiration $\left(\mathrm{ET}_{0}\right)$. Results show that $\mathrm{ET}_{0}$ values calculated by Priestley-Taylor and Blaney-Criddel formulas were more or less similar to Penman-Monteith. The $\mathrm{ET}_{0}$ values found by Hargreaves-Temperature and Hargreaves-Radiation were twice the values calculated by Penman-Monteith formula. We also found good correlations between the reference evapotranspiration calculated by the Penman-Monteith equation and that calculated by Priestley-Taylor and Blaney-Criddel equations in all bioclimatic stages (R2 more than $0.85, \mathrm{p}<1 \%$ ). The $\mathrm{ET}_{0}$ sensitivity analysis has shown that solar radiation and air temperature (energetic climatic parameters) have the dominant effect on the $\mathrm{ET}_{0}$ at the level of the different climatic regions. Accordingly, in the case of lack of some climatic parameters and in sub-humid, semi-arid and arid conditions and for the different phenological stages of the olive tree, we can use
\end{abstract}

Received July 9, 2019

Accepted

December 26, 2019

Released December 31, 2019

Full Text Article

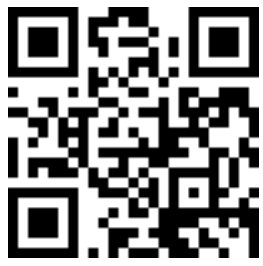

(D) 0000-0002-2104-7567 Amani Bchir

(D) 0000-0002-5757-0616 Fethi Ben Mariem

(D) 0000-0003-1583-5062 Najet Boukherissa

(D) 0000-0002-6543-1288 Wafa Gariani

(D) 0000-0003-3223-2271 Haifa Sbaii 
Priestley-Taylor and/or Blaney-Criddle formulas to estimate water needs.

Keywords: Reference evapotranspiration; Olive; Water requirement; Bio-climatic stages.

\section{Introduction}

Climate change is imposing an additional burden on water management in areas where water resources are already strained in the rationale for the provisions (Levina, 2006). These changes are mainly concentrated in the northern hemisphere, particularly in the Mediterranean areas, which are known for their pronounced climate variability (Hedger and Cacouris, 2008). The temperature in these areas will increase with an average of $0.8^{\circ} \mathrm{C}$ to $1.3^{\circ} \mathrm{C}$ by 2020. In contrary, we will observe a decrease in precipitation from -5 to $-8 \%$ concerning all seasons without exception (Stocker et al., 2013). Tunisia, located at the southern shore of the Mediterranean and forming part of these vulnerable zones, also presents a progressive scarcity of water resources essentially in the field of agriculture.

The olive tree is one of the most adapted species to water scarcity and drought condition. That is why the olive sector is a strategic sector in the Tunisian economy. Indeed, Tunisia's olivegrowing heritage is estimated at more than 82 million trees, which cover an area of 1,835,000 hectares, representing around $30 \%$ of the agricultural area (DGPA, 2015; Jackson et al., 2015). Today, even if the olive oil sector continues to be competitive and plays an important role in the country's economy, several weaknesses and threats persist (Karray, 2012). Unfortunately, this sector suffers from the instability of production from one year to other due to inter and annual irregularity of the rains. The high variability of production from one year to the next, significantly, affects the regularity of export flows, which causes significant fluctuations in the national and international markets. To cope with this situation, the use of olive trees in intensive mode is an efficient solution.

In this context, it is necessary to optimize irrigation by a real estimation of the water needs. According to Pereira et al. (2007) the sustainability of water resources depends on the technologies helping to decide: "When and how much irrigate". The estimation of water needs was carried out using different methods integrating the maximum parameters of the soil-plant-atmosphere continuum. Some research relates to the use of the climate method, which boils down to estimate reference and cultural evapotranspiration. Each of these methods is based on a set of climatic parameters.

A large number of formulas were used, developed and improved to calculate the water consumed in the form of daily or monthly reference evapotranspiration $\left(\mathrm{ET}_{0}\right)$ (Blaney and Criddle, 1950; Priestley and Taylor, 1972; Hargreaves and Allen, 2003; Bois et al., 2005; Summer and Jacobs, 2005; Temesgen et al., 2005; Alkaeed et al., 2006; Papova et al., 2006; Lovelli et al., 2008; Martinez and Thepadia, 2010; Todorovic et al., 2013; Raziera and Pereira, 2013; Masmoudi-Charfi and Habaieb, 2014; Bchir 2015). The Penman-Monteith equation (ET $\left.\mathrm{E}_{0}-\mathrm{PM}\right)$, which according to FAO (1998) is considered to be the most rational and reliable approach, requires an important set of climatic parameters. The use of 
other equations that are less complicated and useless climate parameters can be a reliable and efficient alternative.

In order to find the least complicated and most adequate evapotranspiration calculation method in different experimental sites of study in Tunisia, we compared the PenmanMonteith equation (ET ${ }_{0}-\mathrm{PM}$ ) with that of Blaney-Criddle (ET $-\mathrm{BC})$, Hargreaves Temperature (ET 0 -HT), Hargreaves Radiation $\left(\mathrm{ET}_{0}-\mathrm{HR}\right)$ and Priestley-Taylor $\left(\mathrm{ET}_{0}\right.$-PT) equations.

\section{Material and methods}

\section{mental sites}

Presentation of the experi-

The study was carried out in three experimental sites spread over three different bioclimatic stages; subhumid (El Hawaria), semi-arid (Enfidha) and arid (Gafsa), characterized by quite divergent climatic parameters and rainfall gradient from $173 \mathrm{~mm}$ to $557 \mathrm{~mm} /$ year respectively for the arid and subhumid regions.. At the level of each experimental field, a meteorological station was installed.

First experimental site at the Subhumibe (El Hawaria)

The study plot is an olive grove planted by the Meski variety, conducted intensively with a spacing of $7 \mathrm{~m} \mathrm{x} 7 \mathrm{~m}$. It is characterized by the following geographic coordinates latitude $36^{\circ} 53^{\prime} \mathrm{N}$; longitude $10^{\circ} 48^{\prime} \mathrm{W}$, and altitude $93 \mathrm{~m}$. During the year of the study (2010), rainfall recorded at this plot was 557 $\mathrm{mm}$ /year (Table 1). Evapotranspiration recorded in the same year is of the order of 1,514 mm/year (Table 1).

\section{Second experimental site at the} semi-arid level (Enfidha)

The study is carried out on an intensive olive variety 'Meski' a square spacing of $7 \mathrm{~m} \times 7 \mathrm{~m}$. It has the following geographical features: altitude $23 \mathrm{~m}$; longitude $10^{\circ} 22^{\prime} \mathrm{E}$; latitude $36^{\circ} 08^{\prime} \mathrm{N}$. At this site and during 2010; rainfall was $295.4 \mathrm{~mm} /$ year, and evapotranspiration was in the order of $1,482 \mathrm{~mm} /$ year (Table 1).

\section{Third experimental site at the Aride (Gafsa)}

The study plot is an olive grove planted by the variety Chemlali conducted in intensive with a spacing of $4 \mathrm{~m} \times 4 \mathrm{~m}$. The geographic coordinates of the site are: latitude $34^{\circ} 28^{\prime} \mathrm{N}$; longitude $5^{\circ} 50^{\prime} \mathrm{E}$ and altitude $350 \mathrm{~m}$. Rainfall recorded during 2010 and at the level of the study plot was $173.5 \mathrm{~mm} /$ year (Table 1). Evapotranspiration was in the order of $1,727 \mathrm{~mm} /$ year (Table 1 ).

Table 1. Environmental conditions (air temperature, relative air humidity, rainfall and evapotranspiration) during the study period at the three experimental fields (National Meteorological Institute, 2010).

\begin{tabular}{|c|c|c|c|c|c|c|c|c|c|c|c|c|}
\hline & \multicolumn{3}{|c|}{ Air temperature $\left({ }^{\circ} \mathrm{C}\right)$} & \multicolumn{3}{|c|}{ Relative air humidity (\%) } & \multicolumn{3}{|c|}{ Rainfall (mm/month) } & \multicolumn{3}{|c|}{ Evapotranspiration (mm/month) } \\
\hline & $\begin{array}{l}\text { Sub-humid } \\
\text { (El Hawaria) }\end{array}$ & $\begin{array}{l}\text { Semi-arid } \\
\text { (Enfidha) }\end{array}$ & $\begin{array}{c}\text { Arid } \\
\text { (Gafsa) }\end{array}$ & \begin{tabular}{c|} 
Sub-humid \\
(El Hawaria)
\end{tabular} & $\begin{array}{l}\text { Semi-arid } \\
\text { (Enfidha) }\end{array}$ & $\begin{array}{c}\text { Arid } \\
\text { (Gafsa) }\end{array}$ & $\begin{array}{l}\text { Sub-humid } \\
\text { (El Hawaria) }\end{array}$ & $\begin{array}{l}\text { Semi-arid } \\
\text { (Enfidha) }\end{array}$ & $\begin{array}{c}\text { Arid } \\
\text { (Gafsa) }\end{array}$ & $\begin{array}{l}\text { Sub-humid } \\
\text { (El Hawaria) }\end{array}$ & $\begin{array}{l}\text { Semi-arid } \\
\text { (Enfidha) }\end{array}$ & $\begin{array}{c}\text { Arid } \\
\text { (Gafsa) }\end{array}$ \\
\hline January & 11.8 & 11.9 & 10.9 & 77 & 69 & 60 & 90.1 & 34.2 & 20.2 & 67 & 65 & 78 \\
\hline February & 13.1 & 13.3 & 13.3 & 77 & 65 & 49 & 79.2 & 42.0 & 0.6 & 70 & 76 & 94 \\
\hline March & 15.1 & 15.0 & 16.2 & 82 & 72 & 47 & 65.3 & 27.8 & 0.1 & 95 & 99 & 132 \\
\hline April & 16.0 & 17.1 & 19.7 & 83 & 78 & 54 & 43.2 & 38.8 & 52.8 & 109 & 107 & 154 \\
\hline May & 19.1 & 20.1 & 22.0 & 76 & 63 & 44 & 19.9 & 12.0 & 2.1 & 160 & 160 & 190 \\
\hline June & 23.5 & 23.7 & 27.6 & 74 & 68 & 41 & 3.0 & 1.2 & 4.8 & 182 & 200 & 215 \\
\hline July & 27.5 & 28.2 & 30.9 & 73 & 62 & 37 & 0.0 & 0.0 & 0.5 & 240 & 241 & 234 \\
\hline August & 27.6 & 27.3 & 30.7 & 72 & 61 & 40 & 0.0 & 0.8 & 0.0 & 205 & 194 & 216 \\
\hline September & 23.4 & 24.4 & 25.6 & 81 & 68 & 50 & 64.1 & 25.8 & 7.7 & 133 & 124 & 152 \\
\hline October & 19.8 & 18.9 & 20.3 & 82 & 76 & 53 & 95.6 & 70.8 & 32.9 & 108 & 88 & 115 \\
\hline November & 16.1 & 16.5 & 14.3 & 80 & 74 & 60 & 68.9 & 36.4 & 35.2 & 78 & 68 & 77 \\
\hline December & 13.2 & 11.6 & 11.6 & 78 & 70 & 56 & 27.7 & 5.6 & 16.6 & 67 & 60 & 70 \\
\hline Total & & & & & & & 557 & 295.4 & 173.5 & 1,514 & 1,482 & 1,727 \\
\hline
\end{tabular}




\section{Measurement of climatic parameters in situ}

Evapotranspiration is conditioned by many factors such as solar radiation, air temperature, relative air humidity, atmospheric pressure and wind speed. The meteorological factors are easily measurable. Indeed, the global solar radiation and the heat flux in the soil are measured regularly every 30 min. For simultaneous determination of air temperature and humidity, a psychrometer is used. The meteorological station placed in the experimental plot also includes an anemometer for wind speed measurements, which is installed $2 \mathrm{~m}$ above the canopy, at a place free from any obstacle (tree). The rain gauge is the basic instrument of precipitation measurement. It indicates the global rainfall precipitated in the interval of time separating two readings (once a day).

\section{methods}

\section{Evapotranspiration calculation}

To calculate $\mathrm{ET}_{0}$, there are a lot of empirical formulas using different climatic parameters (Masmoudi-Charfi and Habaieb, 2014; Bchir, 2015). The use of the different empirical formulas depend on available weather data. Climatic data allow us tocalculate evapotranspiration using the following formulas:

\begin{tabular}{|c|c|c|}
\hline Method & Equation & Used parameters \\
\hline $\begin{array}{l}\text { Blaney-Criddle } \\
\text { (1950) }\end{array}$ & $\mathrm{ET}_{\mathrm{o}}=\mathrm{P} \times(0,46 \mathrm{t}+8)$ & $\begin{array}{l}\text { t: Monthly mean air temperature } \\
\left({ }^{\circ} \mathrm{C}\right) . \text { P: the average daily } \\
\text { percentage of annual diurnal } \\
\text { hours as a function of latitude. }\end{array}$ \\
\hline $\begin{array}{l}\text { Hargreaves } \\
\text { Température (Bois } \\
\text { et al., 2005) }\end{array}$ & $\mathrm{ET}_{\mathrm{o}}=0,0023 \times \mathrm{R}_{\mathrm{A}} \times \mathrm{TD}^{0,5} \times(\mathrm{T}+17,8)$ & $\begin{array}{c}\mathrm{R}_{\mathrm{A}} \text { : Extraterrestrial radiation } \\
\left(\mathrm{cal} / \mathrm{cm}^{2} \cdot \text { day }^{1}\right) \text {; TD: difference } \\
\text { between maximum temperature } \\
\text { and minimum temperature }\left({ }^{\circ} \mathrm{C}\right) ; \\
\text { T: Monthly mean air temperature } \\
\left({ }^{\circ} \mathrm{C}\right) \\
\end{array}$ \\
\hline $\begin{array}{c}\text { Hargreaves } \\
\text { Radiation (Bois et } \\
\text { al., 2005) } \\
\end{array}$ & $\mathrm{ET}_{0}=0,0135 \times(\mathrm{T}+17,8) \times \mathrm{RS}_{\mathrm{S}}$ & $\begin{array}{l}\text { T:Daily mean air temperature } \\
\left({ }^{\circ} \mathrm{C}\right) \text {. Rs:solar radiation }\left(\mathrm{MJ} / \mathrm{m}^{2}\right) \text {. }\end{array}$ \\
\hline $\begin{array}{l}\text { Priestley-Taylor } \\
\text { (Hargreaves and } \\
\text { Allen, 2003) }\end{array}$ & ET0 $=\alpha \frac{\Delta}{(\Delta+\gamma)}(\mathbf{R n}-\mathbf{G})$ & $\begin{array}{c}\alpha: \text { an empirical correction for our } \\
\text { case we used } \alpha=1,26 \text { (Sumner } \\
\text { and Jacob, } 2005), \text { Rn: net } \\
\text { radiation }\left(\mathrm{W} / \mathrm{m}^{2}\right) \text {, G: soil heat } \\
\text { flux }\left(\mathrm{W} / \mathrm{m}^{2}\right) \text {, the slope of the } \\
\text { vapour pressure curve }\left(\mathrm{kPa} /{ }^{\circ} \mathrm{C}\right) \text {; } \\
\gamma \text { : psychrometric constant } \\
\left(\mathrm{kPa} /{ }^{\circ} \mathrm{C}\right) .\end{array}$ \\
\hline $\begin{array}{l}\text { Penman-Monteith } \\
\text { (Allen et al., 1998) }\end{array}$ & $\mathrm{ET}_{0}=\frac{0.408 \Delta\left(\mathrm{R}_{\mathrm{n}}-\mathrm{G}\right)+\gamma \frac{900}{\mathrm{~T}+273} \mathrm{U}_{2}\left(\mathrm{e}_{\mathrm{a}}-\mathrm{e}_{\mathrm{d}}\right)}{\Delta+\gamma\left(1+0.34 \mathrm{U}_{2}\right)}$ & $\begin{array}{l}\text { Rn: net radiation at the surface of } \\
\text { culture }\left(\mathrm{MJ} / \mathrm{m}^{2} \text {.day); G: soil heat }\right. \\
\text { flux }\left(\mathrm{MJ} / \mathrm{m}^{2} \text {.day)T: mean air }\right. \\
\text { temperature at } 2 \mathrm{~m}\left({ }^{\circ} \mathrm{C}\right) ; \mathrm{U}_{2} \text { : wind } \\
\text { speed measured at } 2 \mathrm{~m}(\mathrm{~m} / \mathrm{s}) ; \\
\left(\mathrm{e}_{\mathrm{s}}-\mathrm{e}_{\mathrm{a}}\right) \text { : vapor pressure deficit } \\
(\mathrm{kPa}) ; \Delta \text { : the slope of the vapour } \\
\text { pressure curve }\left(\mathrm{kPa} /{ }^{\circ} \mathrm{C}\right) ; \gamma: \\
\text { psychrometric constant }\left(\mathrm{kPa} /{ }^{\circ} \mathrm{C}\right) \\
\text { and } 0.34 \text { : coefficient of the wind } \\
(\mathrm{s} / \mathrm{m}) ;\end{array}$ \\
\hline
\end{tabular}




\section{Results and discussion}

\section{Calculation of reference evapotranspiration (ET)}

Figure 2 reports the results of the application of different methods to estimate $\mathrm{ET}_{0}$ in different bioclimatic stages (subhumid at El Hawaria; semiarid at Enfidha and arid at Gafsa). The values obtained show that the reference evapotranspiration varies considerably according to the calculation method. While admitting that the PenmanMonteith formula is the reference method. The variation in the difference between the values recorded by the Penman-Monteith method and the other methods generally depends on the variation of the climatic factors involved in each formula.

The comparison between the different methods at the three study stations shows that the evapotranspiration values calculated by the methods of Hargreaves Temperature $\left(\mathrm{ET}_{0}-\mathrm{HT}\right)$ and Hargreaves Radiation $\left(\mathrm{ET}_{0}-\mathrm{HR}\right)$ are the most overestimating methods compared to values found by Penman-Monteith formula ( $\left.\mathrm{ET}_{0}-\mathrm{PM}\right)$. The work carried out in Portugal by Paredes and Rodrigues (2010), showed that there is a small error when using the HT equation with respect to that of $\mathrm{PM}$, this error is more important at the level of wetlands compared to arid regions. According to Alexandris et al. (2008) and Martinez and Thepadia (2010), in a humid climate, the equation of HT overestimates the $\mathrm{ET}_{0}$ with respect to the $\mathrm{ET}_{0}$-PM.
The Priestley-Taylor $\left(\mathrm{ET}_{0}-\mathrm{PT}\right)$
and the Blaney-Criddle
$\left(\mathrm{ET}_{0}-\mathrm{BC}\right)$ methods give $\mathrm{ET}_{0}$ values similar to those calculated by the Penman-Monteith formula $\left(\mathrm{ET}_{0}-\mathrm{PM}\right)$ throughout the study year and the 3 bioclimatic studied stages (Figure 2). Similar results have found by Alexandris et al. (2008). This can be explained by the fact that solar radiation, which constitutes the energetic part of both formulas, is the major factor controlling evapotranspiration (Xiaoying and Erada, 2005; Bchir, 2015). Generally, the variation of values recorded by the Penman-Monteith method and the other methods depends on the variation of the climatic factors involved in each formula. The PM method has more accurate values compared to other methods, because of its large number of parameters involved in the formula. On the other hand, the other formulas are limited to the global solar radiation and/or the average air temperature, which generates values of less precision. Also, the overestimation of the $\mathrm{ET}_{0}$ recorded by the other methods (other than PM) could be explained by the use of the average data in the formula which considerably increases the variation of the $\mathrm{ET}_{0}$ (Baldy, 1998), especially in the hot period of the year (High radiation and temperature). In the same context, Bouhlassa and Paré (2006) found that the Blaney-Criddle and Hargreaves methods overestimate the reference evapotranspiration compared to that calculated by the Penman-Monteith method. 


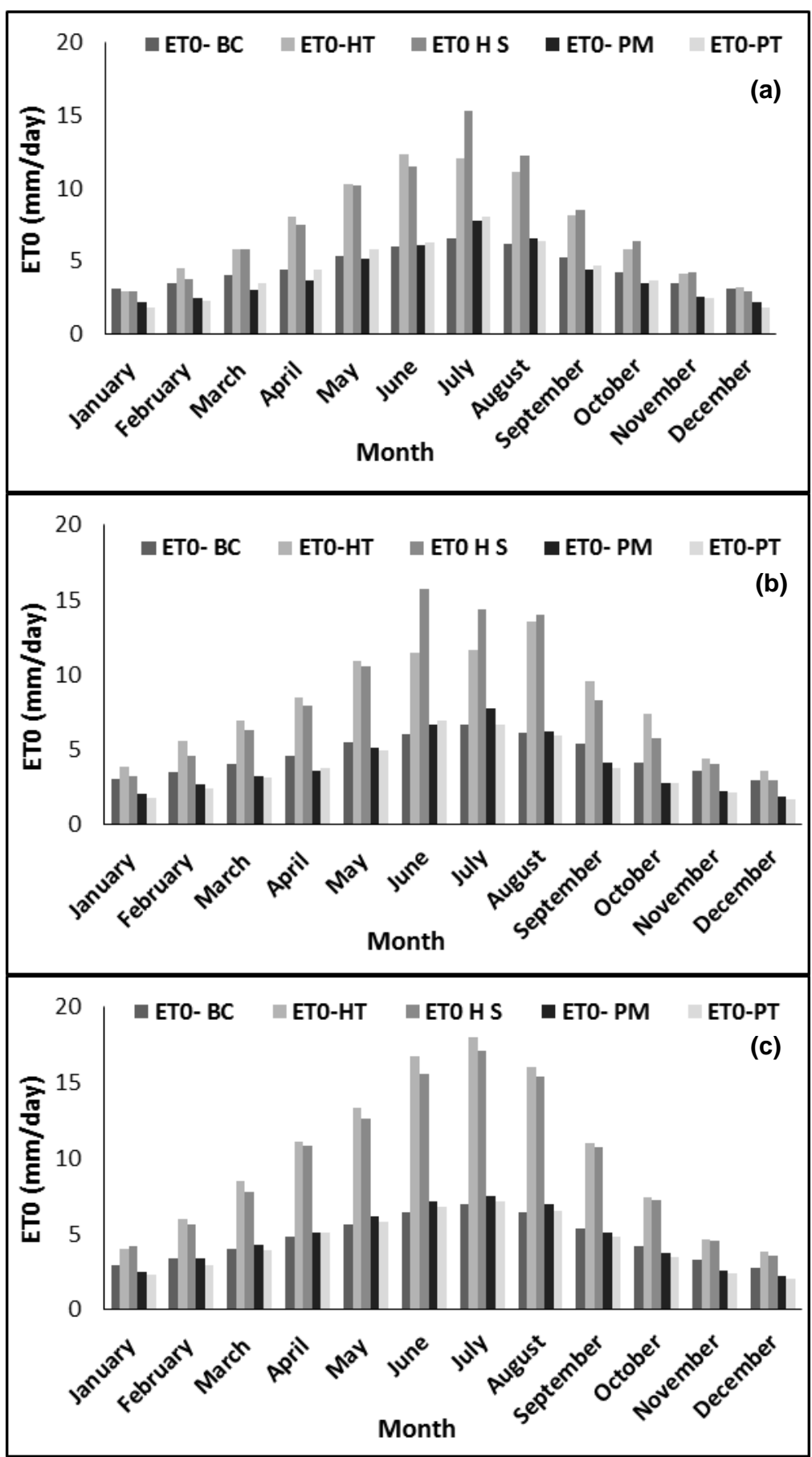

Figure 2. Reference evapotranspiration $\left(\mathrm{ET}_{0}, \mathrm{~mm} / \mathrm{day}\right)$ values estimated by several methods: Penman-Monteith (ET $0-\mathrm{PM})$, Blaney-Criddle $\left(\mathrm{ET}_{0}-\mathrm{BC}\right)$, Hargreaves Temperature (ET $\left.{ }_{0}-\mathrm{HT}\right)$, Hargreaves Radiation (ET $\left.{ }_{0}-\mathrm{HR}\right)$ and Priestley-Taylor (ET 0 -PT) during the year 2010. (a) El Hawaria: Subhumid, (b) Enfidha: Semi-arid, and (c) Gafsa: Arid. 

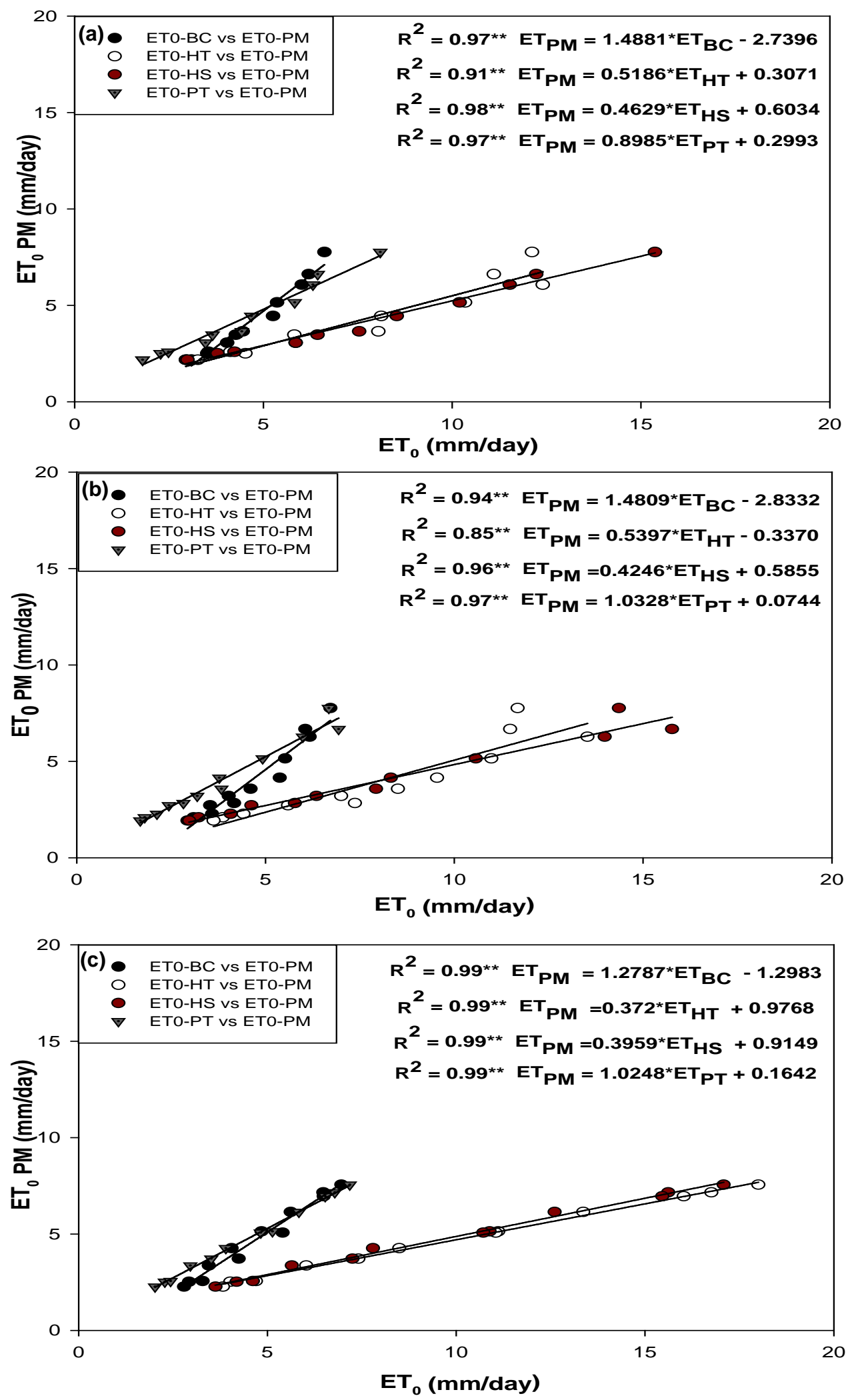

Figure 3. Linear correlation between of $\mathrm{ET}_{0}$ calculated by the method of Penman-Monteith and several methods: Blaney-Criddle $\left(\mathrm{ET}_{0}-\mathrm{BC}\right)$, Hargreaves Temperature $\left(\mathrm{ET}_{0}-\mathrm{HT}\right)$, Hargreaves Radiation (ETo-HR) and Priestley-Taylor (ETo-PT). (a) El Hawaria: Subhumid, (b) Enfidha: Semiarid, and (c) Gafsa: Arid. 


\section{Correlations between the different calculating formulas}

In order to understand the difference between the used methods, the linear regression $\left(\mathrm{ET}_{0}-\mathrm{PM}=\mathrm{ax}+\mathrm{b}\right)$ was studied between the $\mathrm{ET}_{0}$ values calculated at the 3 bioclimatic stages (Subhumid, Semi-arid, Arid). The effectiveness of the empirical methods with respect to the Penman-Monteith formula $\left(\mathrm{ET}_{0}-\mathrm{PM}\right)$ was evaluated in all the study sites in the graphical representation of Figure 3. Highly significant and positive correlations are observed between the Penman-Monteith and the various other formulas, with R2 values exceeding $0.85 \quad(p<1 \%)$. By analyzing the linear regression equations, the Priestley-Taylor formula gives the $\mathrm{ET}_{0}$ values closest to those found by the Penman-Monteith formula. According to Priestley and Taylor (1972), it is sufficient to have solar radiation for the determination of evapotranspiration. Bois et al. (2007) showed that the $\mathrm{ET}_{0}$ calculated by the Priestley-Taylor formula has a highly significant correlation with the $\mathrm{ET}_{0}$ calculated by the Penman-Monteith method (R2 $=0.94$, $\mathrm{p}<1 \%$ ). The Blaney-Criddle (BC) equation also gives similar $\mathrm{ET}_{0}$ values (with a lowestimation) to those recorded by the Penman-Monteith (PM) equation. In the case of lack of climate data, Masmoudi-Charfi and Habaieb (2014) found that the Blaney-Criddle formula is positively correlated with the PenmanMonteith equation in different bioclimatic stages of Tunisia. However, the same authors concluded that, at the phenological scale of the olive tree, this formula is effective only during the vegetative rest, the vegetation development, the beginning of the flowering, the fruit growth, the oil synthesis and ripening of olives.

\section{$\mathrm{ET}_{0}$ sensitivity study to climatic parameters}

Variation in climatic parameters directly and differently affects evapotranspiration $\left(\mathrm{ET}_{0}\right)$ (Goyal, 2004; Gong et al., 2006; Gao et al., 2016). This variation has been studied at the three experimental stations (El Hawaria, Enfidha and Gafsa). A variation of $10 \%$ for the different climatic parameters, involved in the calculation of $\mathrm{ET}_{0}$ by the Penman-Monteith formula, has been established. At the El Hawaria (Subhumid) station, the increase in the relative air humidity by around $10 \%$ in 2010 decreases the $\mathrm{ET}_{0}$ in a clear way (Figure 4). Indeed, this decrease varies from $7.7 \%$ (July) to $18.4 \%$ (December). The effect of solar radiation increase is month dependent. The highest increases values in $\mathrm{ET}_{0}$ followed by an increase of $10 \%$ in solar radiation are observed from April to November. The same evolution was found in air temperature but with less importance. The wind speed did not show any significant effect concerning other climatic parameters. $\mathrm{ET}_{0}$ varies within a range of $-0.7 \%$ to $1.5 \%$ due to an increase $(10 \%)$ in wind speed.

At the Enfidha (semi-arid) station, an increase of the radiation $(10 \%)$ induces an average increase of $7.5 \%$ in $\mathrm{ET}_{0}$ (Figure 4). The effect of radiation is less important during the winter months (about 6.4\%). From March to August, the effect of air temperature is considered as the second important parameter. The effect of relative air humidity decreases in summer but it is remarkable during the rest of the year, with an average varying from $-6 \%$ to $10 \%$. The wind speed, at the semi-arid level as well as at the subhumid level, does not show a significant effect in comparison with the other climatic factors on the $\mathrm{ET}_{0}$ variations.

In the Arid Region of Gafsa, net radiation is the most important factor in the $\mathrm{ET}_{0}$ calculation (between $6.4 \%$ and $7.6 \%$ ) throughout the year (Figure 4.c). The air temperature shows a side effect on the increase of the $\mathrm{ET}_{0}$, concerning the radiation. Rising of the relative air humidity decreases the $\mathrm{ET}_{0}$ value by 
about $-3.8 \%$ during the winter months. In comparison with other stations (subhumid and semi-arid), the relative air humidity affects $\mathrm{ET}_{0}$ less during the rest of the year and more specifically during the summer months. The effect of the wind speed (U2) on the $\mathrm{ET}_{0}$ does not exceed $1.6 \%$ for a $10 \%$ increase in $U_{2}$.

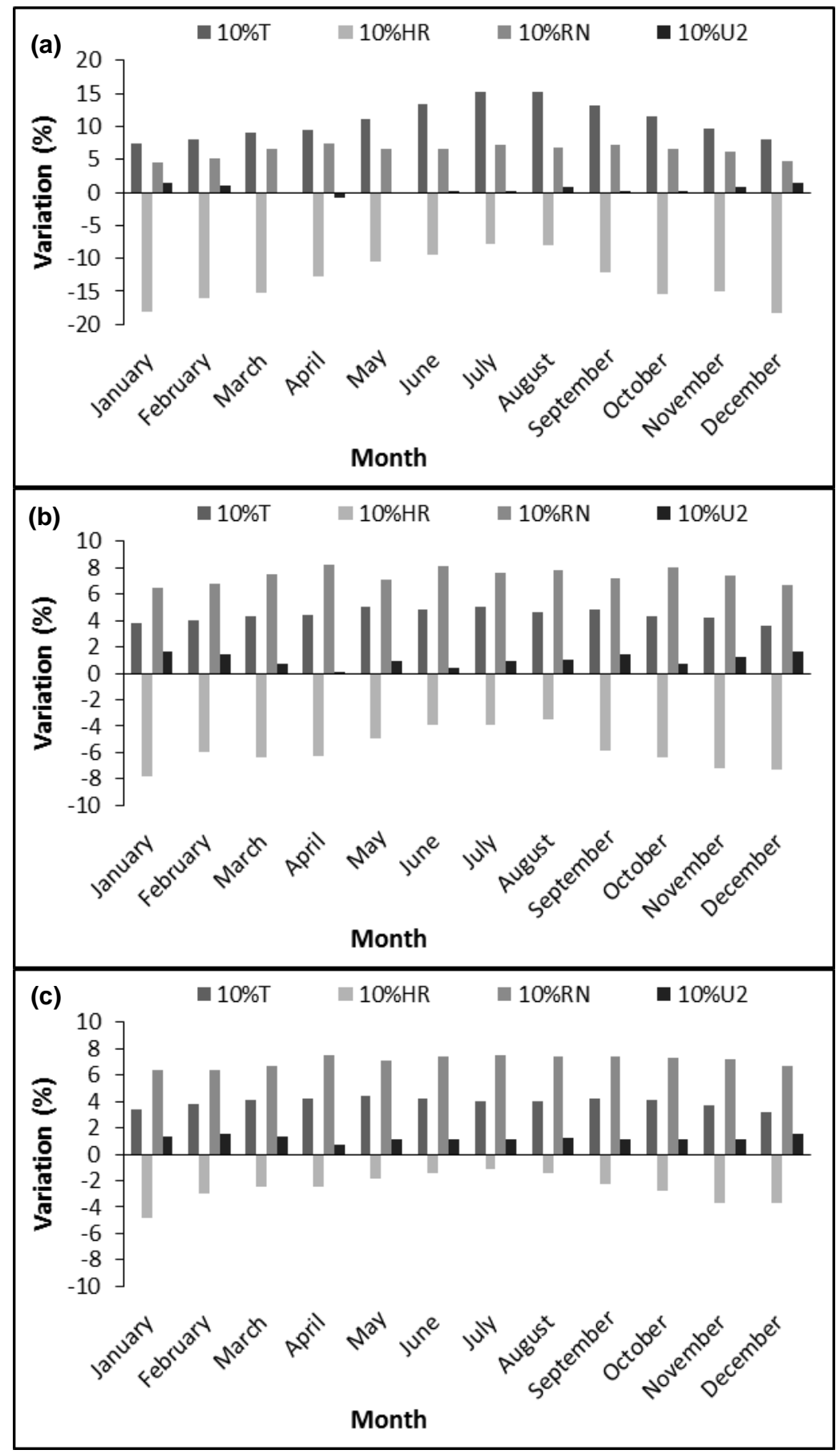

Figure 4. Reference evapotranspiration sensitivity to climatic parameters. (a) El Hawaria: Subhumid, (b) Enfidha: Semi-arid, and (c) Gafsa: Arid. T: Air temperature; HR: relative air humidity; RN: Net radiation and $\mathrm{U}_{2}$ : Wind speed. 


\section{Analysis of the correlations between the reference evapotrans- piration $\left(\mathrm{ET}_{0}\right)$ and the different climatic parameters}

To understand the relationships between the different $\mathrm{ET}_{0}$ calculation methods, it is important to see the effect of climate parameters and their interactions with $\mathrm{ET}_{0}$. The correlation coefficients between the $\mathrm{ET}_{0}$ and the different climatic parameters studied are shown in Table 2 . Results showed that at different bioclimatic studied stages, the $\mathrm{ET}_{0}$ is positively and significantly correlated with the net radiation (R2 $=0.97, p<1 \%)$, the mean air temperature (R2 $=0.91, \mathrm{p}<1 \%$ ) and the vapor deficit pressure $(\mathrm{R} 2=0.79, \mathrm{p}<1 \%$ ). Whereas, the relative air humidity shows a negative and significant correlation (R2 $=-0.35, \mathrm{p}<1 \%$ ) with $\mathrm{ET}_{0}$. According to various authors, the most affecting parameters on variations of evapotranspiration are air temperature, humidity, wind speed and sun radiation (Wrachien and Mambretti, 2015; Yannopoulos et al., 2015; Khoshravesh et al., 2017; Valipour, 2017).

These results show also that the dominant parameter of $\mathrm{ET}_{0}$ is solar radiation, which constitutes the energetic part of the Penman-Monteith equation. Several authors have similarly found the high sensitivity of the Penman-Monteith formula to changes in solar radiation (Bois et al., 2007; Xu et al., 2006; Yang et al., 2009; Tabari and HosseinzadehTalaee, 2014).

Table 2. Matrix of correlations between $\mathrm{ET}_{0}$ and the different climatic factors.

\begin{tabular}{ccccccc}
\hline & Tm & HR & RN & $\mathbf{U}_{2}$ & VPD & $\mathbf{E T}_{\mathbf{0}}$ \\
\hline Tm & 1,00 & $-0,31^{*}$ & $0,83^{* *}$ & $0,02^{\mathrm{NS}}$ & $0,78^{* *}$ & $0,91^{* *}$ \\
$\mathbf{H R}$ & & 1,00 & $-0,33^{*}$ & $0,69^{* *}$ & $-0,79^{* *}$ & $-0,45^{* *}$ \\
$\mathbf{R N}$ & & & 1,00 & $0,14^{\mathrm{NS}}$ & $0,65^{* *}$ & $0,97^{* *}$ \\
$\mathbf{U}_{\mathbf{2}}$ & & & & 1,00 & $-0,39^{* *}$ & $0,04^{\mathrm{NS}}$ \\
$\mathbf{V P D}$ & & & & & 1,00 & $0,79^{* *}$ \\
$\mathbf{E T}_{\mathbf{0}}$ & & & & & & 1,00 \\
\hline
\end{tabular}

** Highly significant correlation $(\mathrm{p}<1 \%)$; ${ }^{*}$ Significant correlation $(\mathrm{p}<5 \%)$ and NS: Not significant correlation. Tm: Mean air temperature; HR: relative air humidity; Rn: Net radiation; $U_{2}$ : Wind speed and VPD: Vapor pressure deficit).

\section{Olive tree water requirements at different phenological stages \\ The comparison between the} different calculation formulas of the $\mathrm{ET}_{0}$ and the analysis of the interaction between the $\mathrm{ET}_{0}$ and the climatic parameters give us the possibility to select the most efficient formulas to estimate of the water requirements for olive tree. The determination of water requirements was based on the FAO formula (ETc $=\mathrm{Kr}^{*} \mathrm{Kc} * \mathrm{ET}_{0}$, Fereres and Castel, 1981).

In our study, the cultural coefficient $(\mathrm{Kc})$ varies between 0.46 and
0.65 (Paster et al., 1998; Bchir, 2010) and the reduction coefficient $(\mathrm{Kr})$ retained for the experimental period was about 0.75 (Bchir, 2010; Elsayed-Farag, 2014). The appropriate formula for calculating $\mathrm{ET}_{0}$ varies according to the bioclimatic stage and the phenological stage of the olive tree (Table 3). The Priestley-Taylor formula is the most efficient compared to Penman-Monteith one during the majority of phenological stages, at the three experimental sites (subhumid, semi-arid and arid). For some stages, it is also possible to use the Blaney-Criddle formula. At the level of the subhumid and 
at the time of flowering (May), this formula gives results close to those found by the Penman-Monteith formula. It also gives ETc values comparable to those estimated by the Penman-Monteith formula in the first place and by that of Priestley-Taylor second, for the flower bud stages (mid-March and April), fruiting and fruit development (June). The Priestley-Taylor formula also keeps its performance in the semi-arid (Enfidha), with the possibility of using the Blaney-Criddle formula from the flowering stage to the fruit growth stage. In the region of Gafsa (Arid), the use of the Blaney-Criddle formula differs on the time scale compared to the first two stations. From the flower induction (February) to the flowering stage (May), it is possible to use this formula.

Masmoudi-Charfi and Habaieb (2014) found that the Blaney-Criddle formula gives estimates of water requirements in the regions of Nabeul and Sousse. In the region of Sidi Bouzid, characterized by a climate similar to that of Gafsa, Masmoudi-Charfi and Habaieb (2014) showed that the formula of Turk, which is based on radiation and temperature was the most adequate.

Table 3. Table 3. Calendar of water requirements of the olive tree based on the most appropriate methods for the estimation of $\mathrm{ET}_{0}$ and determined by phenological stages at the different bioclimatic stages.

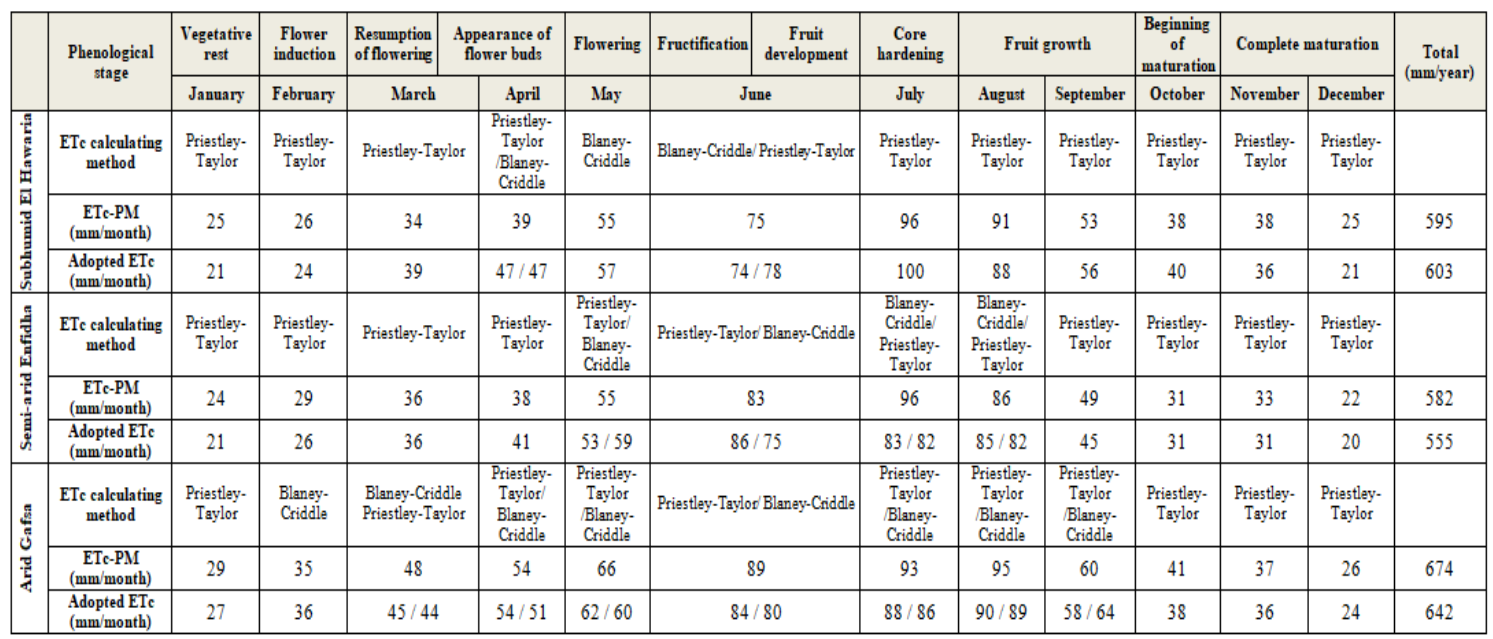

\section{Conclusions}

Adequate and correct estimation of $\mathrm{ET}_{0}$ is so important in agricultural and hydrological studies, water resources and watershed management. In particular, it is necessary to support irrigation scheduling. Our results showed that the Priestley-Taylor equation $\left(\mathrm{ET}_{0}-\mathrm{PT}\right)$ seems to reduce the risk of $\mathrm{ET}_{0}$ overestimation, followed by the BlaneyCriddle equation $\left(\mathrm{ET}_{0}-\mathrm{BC}\right)$. The formulas of Hargreaves Temperature $\left(\mathrm{ET}_{0}-\mathrm{HT}\right)$ and Hargreaves Radiation (ETo-HR) overestimate $\mathrm{ET}_{0}$. The sensitivity of analysis of $\mathrm{ET}_{0}$ to different climatic parameters shows that the climatic energetic parameters ( $\mathrm{Rn}$ and $\mathrm{Tm}$ ) have the dominant effect on the $\mathrm{ET}_{0}$. This explains the strong correlations found between the $\mathrm{ET}_{0}$ calculated by the Penman-Monteith formulas ( $\left.\mathrm{ET}_{0}-\mathrm{PM}\right)$, Priestley-Taylor ( $\left.\mathrm{ET}_{0}-\mathrm{PT}\right)$ and BlaneyCriddle (ETo-BC).This allowed the determination of olive tree water requirements scheduling based on the 
most appropriate methods and corresponding to each phenological stages at different bioclimatic regions.

As a result, in the case of lack of certain climatic parameters and in Tunisian sub-humid, semi-arid and arid conditions, the use of the PriestleyTaylor equation and/or the BlaneyCriddle equation for estimating water requirements is easier than the rest of equations. This could be important for more economical management of water inputs, particularly in the irrigated public and private areas.

\section{Acknowledgements}

The authors wish to thank the Flemish Interuniversity Council (VLIR) for supporting this study as part of a larger Own Initiatives project (ZEIN2006PR326).

\section{Conflict of interests}

Authors declare that there are no conflicts of interest.

\section{References}

Alexandris, S.; Stricevic, R.; Petkovic, S. Comparative analysis of reference evapotranspiration from the surface of rainfed grass in Central Serbia, calculated by six empirical methods against the Penman-Monteith formula. European Water, v. 21, no. 22, p. 17-28, 2008.

Alkaeed, O.; Flores, C.; Jinno, K.; Tsutsumi, A. Comparison of several reference evapotranspiration methods for Itoshima Peninsula Area, Fukuoka, Japan. Memoirs of the Faculty of Engineering, Kyushu University, v. 66, p. 1-14, 2006.

Allen, R. G.; Pereira, L. S.; Raes, D.; Smith, M. Crop evapotranspiration: Guidelines for computing crop water requirements. Rome Italy: Food and Agriculture Organaization, 1998.

Baldy, C. Agro-météorologie et développement des régions arides et semi-arides. Paris: Institut National de la Recherche Agronomique, 1998. p. 63-79.
Bchir, A. Etude de l'évapotranspiration et des besoins en eau de l'olivier de table (cv. meski) conduit en intensif. ChottMariem: Institut Supérieur Agronomique de Chott-Mariem, 2010. (Mastère en Agriculture Durable).

Bchir, A. Etude de l'évapotranspiration et de la transpiration pour l'estimation des besoins en eau de l'olivier (Olea europaea L.) conduit en intensif dans différents étages bioclimatiques. Chott-Mariem: Institut Supérieur Agronomique de ChottMariem, 2015. (Thèse de doctorat en Sciences Agronomiques).

Blaney, H. F.; Criddle, W. D. Determining water requirements in irrigated areas from climatologically and irrigation data. Washington: USDA, 1950. (SCS TP 96 48).

Bois, B.; Pieri, P.; Van Leeuwen, C.; Gaudillère, J. P. Sensitivity analysis of Penman-Monteith evapotranspiration formula and comparison of empirical methods in viticulture soil water balance. Proceeding of the XIV international GESCO Viticulture Congress, Geisenheim, Germany, p. 187-193, 2005.

Bois, B.; Pieri, P.; Van Leeuwen, C.; Wald, L.; Huard, F.; Gaudillere, J.-P.; Saur, E. Using remotely sensed solar radiation data for reference evapotranspiration estimation at a daily time step. Agricultural and Forest Meteorology, v. 148, p.619-630, 2007. https://doi.org/10.1016/j.agrformet.2007.11 .005

Bouhlassa, S.; Paré, S. Évapotranspiration de référence dans la région aride de Tafilalet au sud-est du Maroc. African Journal of Environmental Assessment and Management, v. 11, p. 1-16, 2006.

DGPA - Direction Générale de la Production Agricole. Ministère de l'Agriculture de Pêche et de Ressources Hydrauliques. Statistique 2015. 2015.

Elsayed-Farag, S. Irrigation scheduling from plant-based measurements in hedgerow olive orchards. Seville: University of Seville, 2014.

Gao, Z.; He, J.; Dong, K.; Bian, X.; Li, X. Sensitivity study of reference crop evapotranspiration during growing season in the West Liao River Basin, China. Theoretical and Applied Climatology, v. 124 , p. 865-881, 2016. https://doi.org/ $10.1007 / \mathrm{s} 00704-015-1453-7$ 
Gong, L. B.; Xu, C.Y.; Chen, D. L.; Halldin, S.; Chen, Y.D. Sensitivity of the PenmanMonteith reference evapotranspiration to key climatic variables in the Changjiang (Yangtze River) Basin. Journal of Hydrology, v. 329, no. $3 / 4$, p. $620-629$, 2006. https://doi.org/ 10.1016/j.jhydrol.2006.03.027

Goyal, R. K. Sensitivity of evapotranspiration to global warming: A case study of arid zone of Rajasthan (India). Agricultural Water Management, v. 69, no. 1, p. 1-11, 2004. https://doi.org/10.1016/j.agwat.2004.03.014

Hargreaves, G. H.; Allen, R. G. History and evaluation of Hargreaves Evapotranspiration Equation. Journal of Irrigation and Drainage Engineering, v. 129, p. 53-63, 2003. https://doi.org/10.1061/(ASCE)07339437(2003)129:1(53)

Hedger, M.; Cacouris, J. Separate streams? Adapting water resources management to climate change. Tearfund, 2008.

Jackson, D.; Paglietti, L.; Ribeiro, M.; Karray, B. Tunisie, analyse de la filière oléicole. Rome: Organisation des Nations Unies pour l'Alimentation et l'Agriculture, 2015.

Karray, B. Enjeux de la filière oléicole en Tunisie et axes de développement dans le nouveau contexte politique. Montpellier: CIHEAM, 2012. (Les notes d'analyse du CIHEAM, 66). Available from: $<$ https://www.iamm.ciheam.org/ress_doc/o pac_css/doc_num.php?explnum_id=9078>. Accessed on: Apr. 23, 2019.

Khoshravesh, M.; Sefidkouhi, M. A. G.; Valipour, M. Estimation of reference evapotranspiration using multivariate fractional polynomial, Bayesian regression, and robust regression models in three arid environments. Applied Water Science, v. 7, p.1911-1922, 2017. https://doi.org/ 10.1007/s13201-015-0368-x

Levina, E. Domestic policy frameworks for adaptation to climate change in the water sector. Part II: Non-Annex 1 Countries lessons learned from Mexico, India, Argentina and Zimbabwe. Paris: Organisation de Coopération et de Développement Économique, 2006.

Lovelli, S.; Perniola, M.; Arcieri, M.; Rivelli, A. R.; Tommaso, T. D. Water use assessment in muskmelon by the Penman-Monteith "onestep" approach. Agricultural Water
Management, v. 95, p. 1153-1160, 2008. https://doi.org/10.1016/j.agwat.2008.04.013

Martinez, C. J.; Thepadia, M. Estimating reference evapotranspiration with minimum data in Florida. Journal of Irrigation and Drainage Engineering, v. 136, p. 494-501, 2010. https://doi.org/10.1061/(ASCE)IR. 1943-4774.0000214

Masmoudi-Charfi, C.; Habaieb, H. Rainfall distribution functions for irrigation scheduling: Calculation procedures following site of olive (Olea europaea L.) cultivation and growing periods. American Journal of Plant Sciences, v. 5, p. 2094-2133, 2014. https://doi.org/10.4236/ajps.2014.513224

Paredes, P.; Rodrigues, G. C. Necessidades de água para a rega de milho em Portugal Continental considerando condições de seca. In: Pereira, L. S.; Mexia, J. T.; Pires, C. A. L. (Eds.). Gestão do risco em secas: métodos, tecnologias e desafíos. Lisboa: Colibri e CEER, 2010. p. 301-320.

Pastor, M.; Hidalog, J.; Vega, V.; Castro, J. Irrigation des cultures oléicoles dans la région de LOMA (Province de Jaèn). Olivae, v. 17, p. 39-49, 1998.

Pereira, A. R.; Green, S. R.; Villa Nova, N. A. Sap flow, leaf area, net radiation and the Priestley-Taylor formula for irrigated orchards and isolated trees. Agricultural Water Management, v. 92, p. 48-52, 2007. https://doi.org/10.1016/j.agwat.2007.01.012

Popova, Z.; Kercheva, M.; Pereira, L.S. Validation of the FAO methodology for computing $\mathrm{ET}_{0}$ with missing climatic data. Application to South Bulgaria. Irrigation and Drainage, v. 55, p. 201-215, 2006. https://doi.org/10.1002/ird.228

Priestley, C. H. B.; Taylor, R. J. On the assessment of surface heat flux and evaporation using large-scale parameters. Monthly Weather Review, v. 100, p. 81-92, 1972. https://doi.org/10.1175/15200493(1972)100<0081:OTAOSH>2.3.CO;2

Razieia, T.; Pereira, L. S. Reference estimation of $\mathrm{ET}_{0}$ with Hargreaves-Samani and FAO-PM temperature methods for a wide range of climates in Iran. Agricultural Water Management, v.121, p.1-18, 2013. https://doi.org/10.1016/j.agwat.2012.12.019

Stocker, T. F.; Qin, D.; Plattner, G. K.; Tignor, M.; Allen, S. K.; Boschung, J.; Nauels, A.; Xia, Y.; 
Bex, V.; Midgley, P.M. (Eds.). Climate Change 2013: The Physical Science Basis. Contribution of Working Group I to the Fifth Assessment Report of the Intergovernmental Panel on Climate Change. Cambridge Cambridge: Cambridge University Press, 2013.

Sumner, D.; Jacobs, J. M. Utility of PenmanMonteith, Priestley-Taylor, reference evapotranspiration, and pan evaporation methods to estimate pasture evapotranspiration. Journal of Hydrology, v. 308, no. 1/4, p. 81104, 2005. https://doi.org/10.1016/ j.jhydrol.2004.10.023

Tabari, H.; Hosseinzadeh Talaee, P. Sensitivity of evapotranspiration to climatic change in different climates. Global and Planetary Change, v. 115, p. 16-23, 2014. https://doi.org/10.1016/j.gloplacha.2014.01. 006

Temesgen, B.; Eching, S.; Davidoff, B.; Frame, K. Comparison of some reference evapotranspiration equations for California. Journal of Irrigation and Drainage Engineering, v. 131, p.73-84, 2005. https://doi.org/10.1061/(ASCE)0733-9437 (2005)131:1(73)

Todorovic, M.; Karic, B.; Pereira, L. S. Reference evapotranspiration estimate with limited weather data across a range of Mediterranean climates. Journal of Hydrology, v. 481, p. 166-176, 2013. https://doi.org/10.1016/j.jhydrol.2012.12.0 34

Valipour, M. Analysis of potential evapotranspiration using limited weather data. Applied Water Science, v. 7, p. 187197, 2017. https://doi.org/10.1007/s13201014-0234-2
Wrachien, D. D.; Mambretti, S. Irrigation and drainage systems in flood-prone areas: The role of mathematical models. Austin Journal of Irrigation, v. 1, no. 1, 1002, 2015. Available from: <https://www.austin publishinggroup.com/irrigation/fulltext/ajiv1-id1002.php>. Accessed on: Apr. 23, 2019.

Xiaoying L.; Erda L. Performance of the Priestley-Taylor equation in the semiarid climate of North China. Agricultural Water Management, v. 71, no. 1, p. 1-17, 2005. https://doi.org/10.1016/j.agwat.2004.07.007

Xu, C. Y.; Gong, L.B.; Jiang, T.; Chen, D.; Singh, V. P. Analysis of spatial distribution and temporal trend of reference evapotranspiration and pan evaporation in Changjiang (Yangtze River) catchment. Journal of Hydrology, v. 327, p.81-93, 2006. https://doi.org/10.1016/j.jhydrol.2005.11.0 29

Yang, G. Y.; Wang, Z. S.; Wang, H.; Jia, Y. W. Potential evapotranspiration evolution rule and its sensitivity analysis in Haihe River Basin. Advances in Water Science, v. 20, no. 3, p. 409-415, 2009.

Yannopoulos, S. I.; Lyberatos, G.; Theodossiou, N.; Li, W.; Valipour, M.; Tamburrino, A.; Angelakis, A. N. Evolution of water lifting devices (pumps) over the centuries worldwide. Water, v. 7, no. 9, p. 5031-5060, 2015. https://doi.org/ $10.3390 /$ w7095031 